\title{
Trying to understand the extreme: school children's narratives of the mass killings in Norway July 22, $201 \mathrm{I}$
}

This article was published in the following Dove Press journal:

Psychology Research and Behavior Management

4 February 2015

Number of times this article has been viewed

\author{
Beate Fosse Jørgensen' \\ Dag Skarstein ${ }^{1,2}$ \\ Jon-Håkon Schultz',3 \\ 'Norwegian Centre for Violence \\ and Traumatic Stress Studies, \\ Oslo, Norway; ${ }^{2}$ Oslo and Akershus \\ University College of Applied \\ Sciences, Oslo, Norway; ${ }^{3}$ Department \\ of Education, University of Troms $\varnothing$, \\ Tromsø, Norway
}

\begin{abstract}
School-aged children have limited resources for coping with exposure to highintensity media coverage of terrorist events. This study explores pupils' meaning-making process of their indirect, media-communicated encounters with a specific terrorist event in Norway. Qualitative in-depth interviews about the July 22, 2011 terror attacks were conducted with 54 pupils aged 6-8 years. Seven months after the attacks, the majority had unanswered questions based on more or less accurate knowledge of the events, and they still experienced fear. The media and peers appeared to be their major source of information and not parents or teachers. These children's narratives, characterized by some detailed facts, limited understanding, and a high degree of fiction, were inadequate for restoring calm and feelings of safety. Examples indicate how teacher-facilitated collaborative activities among pupils dealing with crisis can provide a way to construct meaning-making by stimulating conversations and reflections, and developing the narrative through a process of metacognition can provide for further learning and new insights. Implications for a proactive teacher role are indicated.
\end{abstract}

Keywords: crisis and terror, meaning-making, media, teacher role

\section{Introduction}

Two acts of terror struck Norway on Friday, July 22, 2011. A right-wing extremist detonated a car bomb in the government high-rise block in downtown Oslo, killing eight people and injuring more than 100, as well as causing significant material damage. The perpetrator then drove to the island of Utøya, where the Labour Party youth organization was holding its annual summer youth camp, attended by 564 people. Disguised as a police officer, the perpetrator gained access to the island by claiming he was part of a security detail assigned to protect the participants. Upon reaching the island he embarked on a mass killing. He chased camp participants around the small island for more than an hour, killing 69, before the police managed to capture him alive. Many were injured and 56 were hospitalized. This presentation of the events is in accordance with the verdict of August 24, 2012 in Oslo Court referred to in this article as the "authorized version".

\section{Children's reactions to terror and disasters}

The aim of terrorism is to create a state of terror in a population and engender demoralization by violating a basic sense of safety. ${ }^{1}$ Studies have indicated that psychological health and social relations can be affected within the population in general, especially for populations living geographically close to the attack. ${ }^{2,3}$ In the days following the 9/11 attacks, a US national sample of adults reported that $35 \%$ of their children showed one or more stress symptoms, and $47 \%$ of the children were worried about their own
Correspondence: Jon-Håkon Schultz Norwegian Centre for Violence and Traumatic Stress Studies, PO Box 18I, Nydalen, 0409 Oslo, Norway Email j.h.schultz@nkvts.no (c) (i) (5) 2015 Jorgensen et al. This work is published by Dove Medical Press Limited, and licensed under Creative Commons Attribution - Non Commercial (unported, v3.0) BY LC License. The full terms of the License are available at http://creativecommons.org/licenses/by-nc/3.0/. Non-commercial uses of the work are permitted without any further permission from Dove Medical Press Limited, provided the work is properly attributed. Permissions beyond the scope of the License are administered by Dove Medical Press Limited. Information on
how to request permission may be found at: http://www.dovepress.com/permissions.php 
safety or the safety of loved ones. ${ }^{4} \mathrm{~A}$ high proportion (28.6\%) of New York City public school pupils showed mental disorders 6 months after the attacks, with higher prevalence among pupils living in close proximity to the World Trade Center site. The data indicated a relationship between level of exposure and child anxiety/depression disorders at the community level. ${ }^{5}$

In their review of disaster victims from 160 samples, Norris et $\mathrm{al}^{3}$ found that school-age children were more likely to be severely affected by disasters than adults. It is argued that children's cognitive abilities and lack of life experience may make them less able to handle acute helplessness, to comprehend and make sense of the world, thus causing loss of perceived safety and perceived social support. Further, being exposed to mass violence such as terrorism and shooting sprees was more likely to result in a higher symptom rate than natural and technological disasters. Shooting sprees and terrorist attacks tend to be random and create acute helplessness and anxiety: they may be more likely than other disasters to shatter beliefs of an invulnerable self and seeing the world as a meaningful and safe place (this summary of research is adapted from Schultz et al). . $, 67,8^{-7,}$

Studies conducted after 9/11 indicated that children and adolescents were exposed to a large number of terror-related news stories. ${ }^{5,9-11}$ On average, children and youth aged 5-18 watched 3 hours of terror-related television news in the week following the $9 / 11$ attacks. ${ }^{4}$ Only $8 \%$ of the parents reported that their children had not followed the news coverage. Children kept searching for information about the terrorist attacks - through television, newspapers, radio and the Internet - several months afterwards. ${ }^{12}$

In the days and weeks following July 22, Norwegian television, radio, newspapers and the Internet provided extensive and detailed coverage of the events. Additional news reports replaced regular programs with images of devastated buildings, people covered in blood, teenagers swimming from Utøya for their lives, and how the terrorist hunted down his defenseless victims. The weekend after the attacks, adult respondents in a national study reported spending extensive amounts of time watching the news: a mean total of 17 hours in Oslo and 16 hours elsewhere in Norway. ${ }^{13}$ However, there is no documentation of how much indirect exposure children had of the massive media coverage, or how they reacted to or understood it.

\section{The process of meaning-making}

Understanding the rationale behind terror can be challenging. Making sense of the events of July 22 may be particularly difficult, because there were two separate attacks. In order to construct a coherent narrative of the bombing of the government headquarters (HQ) and the mass killing of teenagers on a small island, one needs to understand the link between the Labour Party government and the youth gathering. The perpetrator held political views radically opposed to those of the Labour Party; by attacking not only the government HQ but also the youth camp, he could secure massive media coverage.

Narrative structuring is our basic cognitive tool for making sense of the world. ${ }^{14-18}$ When something unexpected and potentially frightening happens, narrative structuring might restore coherence and meaning. There is a certain kind of narrative that we are concerned with in this study: stories that are not the result of direct experience with the world but are mediated stories. Like adults, children today meet the world more insistently textualized and mediated than anything experienced in the past. As the focus of this study, children 6-8 years old construct stories - sometimes in cooperation with adults, although more often not - but all of them choose raw material from stories mediated through mass media. More iconic depictions of how cognitive and linguistic development takes shape include children's negotiation of meaning with adults. Bruner ${ }^{18}$ described such meaning-making processes as an interaction that occurs between a parent and a child in book-reading routines: questionings, comments, exclamations, confirmations of the child's reactions. But in a social world where the mass media serves as a primary source of information, more traditional perspectives on children's meaning-making processes are challenged.

Meaning is always constructed through/by something, and this "something" is considered here to be language. Language mediates meaning through stories. A story is never neutral. It is told from a subjective perspective and is always one of many possible versions. Truth is not important for a story to make sense. What is important is its cultural probability: ${ }^{14,19}$ is the story believable? Further, stories are a reaction to an unexpected happening. ${ }^{18}$ When the world is as we expect it to be, there is no story to be told. The story is about the exception, the rupture with the usual. ${ }^{20}$ Thirdly, a story must be interpreted as applying meaning to the unusual sequence of events. Interpretation is the means for understanding what has happened, and for finding answers for how it could happen.

At the start of the school year, 3 weeks after the attacks, the Ministry of Education implemented a national intervention strategy for classroom communication, aimed at helping pupils to find answers. ${ }^{6}$ Teachers were encouraged to take an active role in helping pupils to deal with the event by 
restoring calm and feelings of safety, and to foster reflection and understanding through classroom communication.

The present study explores school children's meaningmaking process in view of the high-intensity media coverage of the terror attacks of July 22 in Norway. The study analyzes the children's meaning-making and the characteristics of the knowledge they acquired.

\section{Method}

\section{Participants and procedures}

Interviews were conducted 7 months after the terror events. The initial contact was established by sending a written request to 18 schools followed by telephone calls. Three schools agreed - two in Oslo and one in the southern part of Norway. Purposive sampling was used and the selection criteria aimed at achieving sex balance and being a pupil in a regular class (either first, second, or third grade, aged 6-8 years). All pupils were individually invited to the interview and informed in an adapted language about their rights to withdraw before they gave their oral consent.

Fourteen classes were invited by the head master to participate. Nine teachers agreed and sent a written letter to all parents in the classes in question. Parents were instructed to explain the topic of the conversation, but not explicitly provide information about the terror events. In total, 56 written or oral consents for participation were received. Two children felt uncomfortable about being taken out of the classroom by the interviewer (a stranger), and thus the interviews did not take place. The final selection consisted of 54 pupils: 25 first-graders, 6 years old; eight second-graders, 7 years old; and 21 third-graders, 8 years old. The pupils were from two schools and nine different classes. There were 29 girls and 25 boys.

Fifteen schools declined to participate, citing lack of time or uncertainties as to whether the topic might frighten the children. Six head teachers refused because they felt it was unsuitable to talk with the youngest pupils about terrifying events that had happened 7 months ago. Also, among the other nine head teachers, it was commonly argued that the children would probably have forgotten and should not be reminded about such terrible events because that might cause harm. The same line of reasoning was expressed when we sought approval for our data collection procedures from the Norwegian Social Data Services: approval was initially granted on condition that a school nurse would be available in case the interview provoked strong reactions among the children. After some discussion, this requirement was dropped.
A semistructured interview with open-ended questions was employed to gather the children's narratives about the terror attacks. The main question asked was: can you tell me about what happened on July 22? Follow-up questions were given to clarify when needed, to ask where they had received their information, if it had been triggered by their own interest, and what their thoughts and feelings after the event were. The underlying purpose was to reveal the children's narratives, without asking questions that might bias the children's story in any way. We wanted to explore both the children's understanding of the events, and the processes by which they had reached this understanding. Hence, we emphasized that there were no right or wrong answers. The interview guide was piloted with four children and adjusted accordingly.

The children were interviewed at their school by the first author. The interviews lasted between 7 and 20 minutes, depending on the children's responses. They were all audiotaped and transcribed verbatim. In addition, the nine teachers were asked to provide background information about their instruction in class concerning the terror attacks.

There were no indications that the interview frightened the pupils in any way. On the contrary, those who came to the interview expressing fear left with reassurance that the perpetrator was in jail, that he would remain in jail, and that the pupil and her/his family were safe. These types of reassurances were provided by the interviewer after the research part of the interview had ended.

The theoretical framework was based on cognitive and narrative psychology, using narratives as cognitive instruments in the children's meaning-making process. ${ }^{15,16,21,22}$ This form of discourse analysis included a phenomenological approach to the qualitative nature of the data: the children's conceptualization of the events at a specific time and specific place approximately 7 month after the attacks. The analysis was explorative, but pointed further to the didactic implications of the stories. This approach to the qualitative data provided access not only to what was said, but equally important, to how it was said.

In order to reach variety within the data set, 54 school children from three different grades, nine different classrooms, and in two different cities in Norway were interviewed and sex balance among the pupils was achieved.

\section{Results and discussion}

Head teachers had generally assumed that the pupils would no longer remember the terror events. This was not the case, we found. Seven months later, only two of the 54 children were 
unable to report their impressions of the events. Otherwise, children could retell detailed episodes, although they struggled to organize events into the correct sequence.

The storyline of July 22 is complicated. Firstly, it possibly contains two narratives, events at two different places in a specific order: the bombing in Oslo, and then the shootings on the island. Secondly, even in the narratives that contained a clear agent (an "unclear" agent in this context refers to an agent with no particular features, usually referred to as "someone"), the intention behind the two events is difficult to grasp.

Only three of the 25 first-graders had a clear conception of the places where the two events took place, and only one of them could order them temporally. Eight had a clear agent, whom they referred to as the villain, thief, the bad man: a clear narrative function. Distinctions like terrorist, attacker, bomber, killer, or the man's name - distinctions more in accordance with the authorized narrative - were not used. Four tried to imagine the agent's reason for acting, with reasons or motives ranging from explanations where the act sprung out of the situation (he was acting spontaneously); to the agent being sick or mad, having played too many war games at night or as a child, being drunk, being angry because immigrants kept coming to Norway; or he had parents who were angry with him, had no friends, or was threatened by someone.

Of the 21 third-graders, nine could order the two events temporally and geographically. Seventeen had a clear agent, and many mentioned him by name. Only one of them denoted the agent using a narrative function. Twelve of them assigned motives; similar to first-graders, they presented various theories: the perpetrator did not agree with the government/the prime minister/the Labour Party; he did not want foreigners to come to Norway, Muslims in particular; he wanted to rule Norway all by himself. Some mentioned that he might have gotten the idea for making a bomb by something he saw on TV, or for buying guns after seeing an advertisement for a "cool" gun. Other theories for his actions were excessive use of alcohol, brain damage, or insanity. Another possibility mentioned was anger after his parents had abandoned him and he grew up in an orphanage and no one cared for him.

The narratives told by the third-graders were far more consistent with the authorized story than those of the first-graders. The two main events - the bombing of the government quarters and the shootings at Utøya - were more often separate and temporally ordered, and the narratives generally had a clear agent. In addition, the narratives were more detailed regarding reasons or causes; more of the thirdgraders had theories as to why the agent acted as he did.

The difference between the first- and third-graders should come as no surprise. What is striking, though, is that the second-graders' narratives were generally as tightly knit as those of the third-graders, and strikingly different from those of the first-graders. In the second-graders' stories, six out of eight had a clear agent, four of the stories were temporally and geographically ordered, and five contained thoughts about the motive. There were only two theories given, both in accordance with the authorized story: the agent was "sick" and he disagreed with "the people in charge".

\section{The stories}

The school emerged as the pupils' weakest source of information about the terror attacks. Our interviewees reported that they had several talks with their parents in the first days and weeks following the attacks. Later, however, neither parents nor teachers appeared to be the main sources of new information for the pupils' meaning-making about the terror attacks. After the first weeks, these children appeared to have been largely left to themselves and the mass media for their ongoing meaning-making.

Television news appeared to be the children's main source of information. All of the children had watched regular newscasts. Some children also reported getting information from "SuperNytt", a news program especially adapted for children. Other media mentioned were the radio, newspapers, and the Internet, mainly Wikipedia and online news.

The media seemed to be an unreliable source for the children. For example, one first-grader was unsure whether anything presented on TV was true. Here, she was mirroring what we may assume she had heard from her parents: "it's just TV":

There's one thing I'm wondering about. Is it for real, or is it just TV? [Girl, 6 years]

One boy's reasoning seemed to describe a belief that what is broadcast in one country happens in that particular country:

Interviewer: But you have seen a little on TV about it?

Boy: Yes, in Thailand. And then it was there too. He was

there, in Thailand too. [Boy, 6 years]

Nineteen of the children constructed stories with a high degree of fiction compared to the authorized story. This story was composed almost entirely of fictional events: 
Something fell down and hit an island. And there were lots of kids there. They had a cabin that was smashed. My big brother rented that cabin. And then this thing came from space. I saw the island on the telly, there were loads of tents there. [...] It was a spaceship that touched something and then it just stopped flying and fell down. [...] I was a little worried that a spaceship should fall on top of our house as well. [Boy, 6 years old]

In the days after the attacks, TV and newspapers were filled with pictures of the island taken from helicopters, zooming in on the island and the tents, just as this boy reports. It appeared that he took from these reports visual impressions, but not much more. From these pictures, he seemed to have constructed a coherent narrative, but one that was far from what actually went on.

The media were the main narrative recourse for the children, but problems with conceptualizing TV made it an unreliable source for their meaning-making. Clearly, these children would have benefited from support in their meaningmaking processes. Before turning to examples of narratives that have been supported, let us present some features of the unsupported narratives.

\section{Folk theories as the basis of intersubjective understanding}

The most frequent deviations from the authorized story appeared when the children gave accounts for the motive behind the attacks. Evidently, as exemplified by the spaceship story, the children left alone in their ongoing meaning making must find meaning and coherence in their own cognitive world. "Mind reading" or intersubjective understanding is a human capacity visible even in babies. ${ }^{19}$ The young children in our study used this capacity to attempt to understand the intentions of the adult perpetrator. We found a great variety of folk theories that revealed the children's intersubjective understanding. Some versions were based on the theory that anger and seeking revenge leads to misdeeds:

I think he was a little angry because somebody shot at him first. I don't know if it was the kids that did it.

[Girl, 6 years old]

I think he was quite angry because somebody said "don't shoot or he'll shoot you". [Girl, 8 years old]

Accounts of the same sort explained the course of events based on the theory that humans act intentionally for personal gain.

Maybe he just wanted Utøya. He wanted to live there. [Girl, 6 years old]
It was because he wanted more money. And he lived on a farm, I think. And there people don't have much money. [Girl, 6 years old]

Some children established coherence and meaning by making use of folk theories based on ideas that the media can powerfully influence and effectively change human behavior:

I think he had seen the TV program: "Don't do this at home," and then he wanted to try a bomb like that, so he got the idea to do it. And then maybe he had thought about it, and then he got the idea about shooting too. [Girl, 8 years]

And I guess it was like this: he'd played lots of wargames when he was a kid, and when he was grown up, he wanted to do it for real. [Boy, 6 years]

\section{Problems of linking two events}

Even with information about what happened, there were still problems linking the two events. Understanding the reasons behind even one of the events is challenging. One girl knew that the motive behind the attacks had something to do with immigration:

Yes, because he doesn't like people who come from other countries. And there were many of those that worked in that building. [Girl, 6 years]

To link her information with the perpetrator's objection to foreigners in Norway, and the bombing of the government $\mathrm{HQ}$, the girl concluded that many immigrants worked there.

Only two participants, both third-graders, had explanations that explicitly connected the agent's project to the Utøya killings:

And he was angry at the prime minister, and the people on Utøya had something to do with him. That's why he shot them, too. [Girl, 8 years]

Girl: But it was in fact because he knew that she - what's her name again, she who was our prime minister for a long time?

Interviewer: Are you thinking about Gro Harlem Brundtland?

Girl: Yes! And he knew that she would come, to Utøya, but it took such a long time and there was traffic jam in town, so he didn't get there on time. [Girl, 8 years]

\section{Open-ended narratives}

Some children had divergent stories possibly because the story was still in the making. As long as the story had no 
end, it seemed that their story had the capacity to exceed the actual events. One example we found in four versions was a continuation of the story where the perpetrator escaped from jail.

Do you know if he has escaped? I think I heard so. I'm not sure, though. [Girl, 6 years]

Associations with other news might cause her uncertainty about where the perpetrator was. This might explain why several of the pupils claimed to have heard that the perpetrator had escaped from jail. The children claimed to have heard this information from media. Another example:

I think it's scary, that photo where he was sitting in the police car and smiling. And then I thought that he would escape and lay another plan. All the time there are new articles in the papers, and then I wonder if he's planned something because all the time there's news about him. [Boy, 8 years]

Fear is often connected to the continuation of the story; the perpetrator escapes, he is not under control, and he is planning new attacks.

\section{A strong narrative template}

One third-grader was very interested in the terrorist attacks. We present here a larger part of her account to reveal that even a story told with great precision in accordance with the authorized story might diverge when it is not closed.

On the telly, I could see lots of flames, and I saw this man shouting: "Hello, does anybody need help?" Luckily the Prime Minister wasn't hurt, but I saw a lady, she had broken glass all over her. She didn't think that was odd. She just got on the bus. Everybody on the bus looked at her, and she didn't understand anything. But when she got home, she looked in the mirror, and then she fainted. [Girl, 8 years]

She explained not only the news from the actual day of the bombing in Oslo, but also news presented in the following months up to the present interview. She was particularly interested in the discussion on whether the perpetrator would be sent to prison or not:

And many of the parents of the kids on Utøya, and of the ones who died in the bomb attack are very angry because they have heard that he is not going to prison but to a nursing home.
At the time of the interviews, the first psychiatric report was being discussed in the media. The report stated that the perpetrator suffered from paranoid schizophrenia, meaning that, by Norwegian law, he could not be sentenced to jail but to psychiatric treatment.

The third-grader's story was accurately retold in accordance with the media coverage until she added an additional element to the narrative: She explained that she saw headlines in the papers that the perpetrator was on the loose in Oslo, and that he had a knife "and then he killed somebody with a knife". There were in fact several knife killings in Oslo during the autumn of 2011. This girl seemingly blended the stories about knife attacks with those of the terrorist events.

Several examples indicated that the narrative existed as a latent narrative template that was generalized, in the sense that other news could be incorporated. As we have seen, one third-grader associated the news about a knife attack with the story of July 22 . In her story, the perpetrator threatened and killed passengers on a bus in order to cover the expenses he had with the attacks.

The incidents connected to the narrative were events from both the news and from the children's own everyday lives:

On New Year's Eve, someone blew up our mailbox. We had to buy a new one. And at first I thought it was a bomb like the one on TV. [Girl, 6 years]

Another first-grader told about a fire drill at her older brother's school. When the alarm went off, the brother and his classmates ran out of the building, covering their heads with their arms, believing it was a bomb attack and that falling bricks would hit them. She further explained that she thought a lot about the acts of terror, and that she felt a lot of bad things had happened lately:

I wonder how it will end. It's all becoming a little ... you

know ... what will happen to Norway now? So many sad things have happened every day. [Girl, 6 years]

\section{Unsupported narratives}

The unsupported narratives were not enough to restore a feeling of safety. Fear was the most frequently reported feeling. Without being prompted, 20 of the 54 children said that the story had frightened them. Bruner ${ }^{18,22}$ showed how folk psychology is negotiated and interacted with through narrative structuring. This concerns our everyday stories, our therapeutic construing of what happens in our everyday lives, as well as media stories, movies, and fictional accounts 
of all kinds. Common to all these is their linear structure: beginning, middle, and end. What secures the meaning of the story is coherence and a logical link between the different happenings, and then the end. Without an end to the story, the meaning making process is challenged..$^{14,15,17,18}$ As the excerpts from our interviews showed, what secures the meaning of a story is not there. The stories have been constructed on the basis of limited information. Left alone in their meaning-making process, the children had to construct their stories from their own sphere of memory and understanding. When one girl explained the detonation of a bomb in government HQ, she built off of information provided: the perpetrator was against immigration. She then concluded - wrongly - that many immigrants were working in the government building, and thereby created both logic and coherence for her story. The stories were made coherent through a child's intersubjective understanding, which was not sufficient to link the two events and not enough to complete the narrative.

As long as the children were not assured that the perpetrator will remain in jail, their narratives of July 22 will not find an ending. The lack of an ending has two consequences: fears that the perpetrator will escape from jail and go on to plan new attacks, and the ability of these non-ended narratives to incorporate other happenings featured in the media or in the child's own everyday life. For some of the children, it seemed that a latent schema for understanding stories of brutality was established. This can be further illuminated by Bruner' ${ }^{18}$ observation that narratives are stored together with the feelings that grow out of the experience. Experiences in the child's everyday life might then be over-dramatized in imagination - as with the girl who thought that the New Year's Eve fireworks that damaged the family mailbox were a bomb, or the class that ran out of the school building during a fire drill, protecting their heads, thinking they were under terror attack.

\section{Getting closer to a completed narrative}

A striking feature of the second-graders' accounts is that six out of eight from the same class added a second narrative to their stories: a girl who outmaneuvered the killer at Utøya. She escaped being killed by lying still, pretending to be dead, and was not shot. Her story was related by many national newspapers only days after the attacks. However, none of the informants from the other classes mentioned this story, with one possible exception, which will be commented on. The second-grader below mentioned the story five times during her interview:
I remember that six died out there. And I remember that there was a girl who lay down pretending she was dead. I saw the girl on SuperNytt (children's news channel) who pretended she was dead. She showed how she lay there. She looked totally dead, but she was only pretending. [...] pretending she was dead. That was pretty smart! [...] And then he came and then the children thought he was a policeman, and then he shot the children. But there was one who made it. She lay down and pretended she was dead. [...] I heard about one who made it. She was in fact really smart. She lay down on the ground and then she waited for an hour until it was safe. [...] Yes, like she was dead. But she was alive. [Girl, 7 years]

The story about the "smart girl" came across as particularly meaningful to the pupils in this second-grade class. Six out of eight participants from that class told the same story. It emerged unsolicited; the interviewer had no questions dealing with that particular event. The pupils mentioned the story repeatedly, up to four and five times during the interviews.

Why is this additional integrated narrative so loaded with meaning for these second-graders? Like most of our participants, these children felt unease when faced with a story of extreme brutality. But with the smart girl on the stage, the protagonist met his antagonist. There is a parallel between the two: the terrorist pretends to be a policeman, but the girl outsmarts him by pretending to be dead. In five of the narratives, it was not a parallel story, but a linked narrative that might be conceptualized as a solution to a plot. This solution represents a kind of happy ending as, by introducing the girl's story as a main feature of the whole narrative, the teller establishes an antithetic situation with a heroine who has a strategy for survival in the face of a lifethreatening situation.

One other participant - a third-grader - who mentioned this story further illuminated the particular meaning of this story. Unlike the second-graders' story, his story was not integrated as part of the narrative about the attacks, but as an example of something remembered from the news:

I've only watched SuperNytt about one that lay under something when all her friends got shot. [Boy, 8 years]

This story carries a distinctly different meaning from that of the second-graders. It does not imply an agent with a strategy for survival: it is a story about a happy coincidence. But when strategy is replaced by coincidence, the story becomes less meaningful and is not linked with the main narrative. 


\section{Facilitated class talk}

Out of 54 participants, seven added a second narrative to the main events of the terror attacks - a narrative that was not part of the authorized story. Six of them were members of the same school class, and these six applied a different meaning to the story than the one who was not in that class. How can this be? Two children reported hearing the story about the clever girl on TV, but so did the third-grader who also had picked up the story, and still there was a distinct difference between his story and that of the second-graders. Moreover, if this was a narrative picked up only from newscasts, surely more children would have mentioned it. The same would be the case if it had been picked up in conversations with friends or parents.

The empirical data indicate that the second-graders' meaning-making process is shaped by a class context. This is further indicated by another synchronized feature of their story. While both the first- and the third-graders had various theories concerning the reasons for the agent's actions, the second-graders had only two - both of them in accordance with the authorized story.

What do we know about this class and the terror attacks? From what these second-graders told us, we know that this class in August, approximately 1 month after the attacks, gathered for a talk about what had happened. This was a ritual the class performed when "something like that happens". They lit a "quiet candle", gathered in a circle, stayed quiet for a moment, and then talked about the events. Everyone had a chance to say something. This was confirmed in our conversations with the teacher. She sought to let all children talk and discuss, interrupting only when necessary to clarify and correct misunderstandings.

The data shows a striking example of the formative effect of this class talk on meaning-making. Some of the characteristic responses of these young children can be explained strictly by accounts of cognitive development. But our empirical data includes examples that went beyond this explanation. Several studies have shown the importance of a collaborative activity for enhancing problem-solving. ${ }^{23}$ What happens in such interactions is that the child's own cognitive approach to the problem is challenged, either directly by peers or by parents' or teacher's scaffolding the pupils understanding, understood as pacing the problem-solving process. The advising adult prompts, questions, explains, summarizes, and connects the pupils' speech acts. In this instance, we can imagine that the teacher mediated common facts for/in collaboration with the children, how to understand these facts, how to follow the plot, and how to understand the characters' activities. This talk differs from the negotiation of meaning between an adult and a child. Firstly, the teacher is backed up by the authority of the school institution. Secondly, and more importantly, this talk is a nonindividualized talk; participants in collaboration create an interpretive community where learning occurs in interaction with others through linguistic cooperation. ${ }^{23}$ In such communities, negotiation of meaning is facilitated and the outcome can include new meaning and new understanding.

The teacher was not active in shaping the second-graders' story. Instead, the characteristics of the story indicates that the children, through the nonindividualized talk, fixed the story themselves. Their stories strongly resembled childhood narratives, with features of the classic fairy-tale structure: equilibrium/disequilibrium/equilibrium restored. Furthermore, these second-graders' stories were shaped over a basic antithetic scheme: with the brave and smart girl in the story, the bad guy meets his match. Appleyard ${ }^{24}$ saw the need for this kind of narrative structure as arising out of a double wish: "to acknowledge anxiety but to be assured of deliverance from it" or to "give concrete form to threatening evil and then to assure that it will be defeated". ${ }^{24}$ The fairytale pattern, with its beginning and middle, where the hero faces hardships that are overcome and defeated in the end, is an expression of the human need to create structure and coherence. ${ }^{20,24}$ This is how we wish our life stories to be.

\section{Development of new questions}

Overwhelmingly, these second-graders' stories seemed to make sense to them. There was a clear agent, and the two main events were temporally ordered; further, there was a clear conceptualization of why these two events happened, with the reason/cause based on a description of the agent's psychological state and political views. Does this mean that there were no questions left for these informants to ask? On the contrary, several important aspects remain unanswered:

Now they've found out that he didn't exactly know what he was doing. It is a little strange that he's in jail when he doesn't know what he has done. [...] Yeah, but I'm thinking that it is a bit sad because when he doesn't know what he has done, then he is not allowed to be out, like other people. [Girl, 7 years]

This girl was referring to the first of the psychiatric reports where the perpetrator was diagnosed with paranoid schizophrenia. Her more philosophical reflections exceeded the intersubjective mode of thinking and led her into a hermeneutic mode where generalization or abstract thinking relies on interpretation of context. 
Bruner ${ }^{19}$ shed light on the nature of such reflections in arguing that a basic function of education was to increase our linguistic awareness in order to improve the human capacity for constructing meanings and realities. "Thinking about thinking" must be a principal ingredient of any empowering practice of education". ${ }^{19}$ The key to more powerful symbolic systems is metalanguage. This language enables monitoring and correcting one's own thinking, acting, and speech acts, what Vygotsky calls "deliberate mastery". ${ }^{25}$ It is usually claimed - in classical philosophy texts at least - that sense of self arises out of the capacity to reflect upon our own acts, by the operation of "metacognition". This second-grader was doing so by questioning her own narrative - a position open for further learning and new insights, a learning that might "improve the capacity for construing meaning and constructing realities". ${ }^{18}$

We found several questions of this kind. Most frequent was the question of why it happened:

At once when I heard about it, I asked: Why did he shoot, why did he do it, why, why, why? [...] They didn't answer me. I kept on asking them. [Girl, 7 years]

Was he sick? [Boy, 8 years]

Is this something that happens all the time?

[Girl, 8 years]

Questions like this lead into a cognitive mode where the answer cannot be underlined, but a cognitive mode where generalization and abstract thinking always needs to take context into consideration; ${ }^{18}$ and the most important context in this case was a clear storyline, constructed with the help of the teacher. Such meta-questions can appear only when the narrative has its most elementary raw material available. But what is strikingly plain in the research on metacognition is that it starts in early childhood, ${ }^{26,27}$ and that self-monitoring and self-correcting can be taught and developed successfully as a skill. ${ }^{20,21,28}$ By questioning their own narrative, these second- and third-graders controlled and monitored their own story, their own version of the world.

This cognitive mode carries the possibility for new insights and new revisions of this in the media's ongoing story as new information is added to the context. A challenging and engaging story widely shared in a community is a resource for learning and for developing thinking about thinking. A teaching that ignores this possibility for these reflections to be communicated misses out on a chance to develop these skills.

\section{Implications}

Access to schools proved to be a challenge in this study: six head teachers refused our request due to their uncertainty about whether it would be suitable to talk with the youngest pupils about such terrifying events. Head teachers generally argued that the children would most likely have forgotten and should not be reminded because it might cause harm. However, we found that the 54 participants had not forgotten about the mass murders. Moreover, nothing in our material indicated that the conversation during the interview frightened them in any way. On the contrary, the majority expressed great interest in talking and revealed several questions that they had formulated, without ever receiving answers.

The school emerged as a weak narrative source for the pupils in making sense of the terror attacks. Our interviewees reported that they had several conversations with their parents in the first days and weeks following the attacks. Later, it appeared that neither parents nor teachers were the main source for providing new information. After the first weeks, the pupils seemed to have been left largely to themselves and to the mass media for their ongoing meaning-making trying to understand the extreme. Seven months after the terror attacks, these children were still showing interest in the events and actively seeking information. Being such a dominant provider of information, the mass media seemed to have challenged the children's meaning-making, especially when constructing meaning and answering the question: "why did he do it"?

A dominant feeling among the 54 pupils we interviewed was fear: fears that it would happen again, that the perpetrator would escape, that he would not be put in prison, and that something awful would happen in the near future. First, the narratives that the majority of the pupils had constructed could not provide them with a sufficient sense of safety. We noted the lack of reassuring information concerning their most basic feelings of trust and safety: will he be put in prison, will he be able to escape, and will he be able to threaten me and my family? Secondly, the high degree of misunderstanding and fiction in the narratives appeared to increase the degree of uncertainty and unpredictability of the (then) upcoming trial of the perpetrator and their basic sense of safety. Thirdly, the problems of conceptualizing TV as a medium were evident in many interviews, and gave rise to insecurities about the credibility of the information conveyed. Fourthly, the stories seemed to have established a narrative template for dramatic events that caused misconceptions by erroneously adding new information to the story of these terror events. 
The unsupported narratives lacked a clear storyline and were generally open-ended. With such open-ended narratives, the children tended to create endings drawn from their daily lives and from their imagination. In several instances, this unsupported search for closure to the narrative appeared to create a narrative template for dramatic events, causing more fear.

The most reassuring information - in addition to information on basic safety concerns like "he will remain in prison" - was the story about the "smart girl". This story was probably picked up from the children's news channel. In the second-graders' class talk, the information was conveyed from child to child, but carefully facilitated and overseen by the teacher. The story shaped the construction of the narrative and in some cases shaped the narrative in such a direction that the story of the smart girl became the most important feature about the terror event.

The second-graders' teacher provided the children with the basic building blocks for a coherent narrative. A coherent story seemed to be the basic condition for the children's scrutiny of their own stories' reliability, ie, for the process of metacognition. By facilitating the children's stories, the teacher laid the groundwork for a paradigmatic/hermeneutic mode of thinking that opened up further learning and new insights.

These findings underscore the importance of a teacherfacilitated collaborative activity among children dealing with indirect crisis as a way of structuring the children's meaning-making. Allowing children to provide their own observations and questions can help to ensure that the pieces of information provided are within the level of the children's cognitive development and can therefore become important building blocks in their meaning-making.

We have emphasized narratives as the most extensive cognitive schema for organizing information and applying meaning to experiences and impressions. Furthermore, we have pointed to the tendencies in the children's narrative structuring that might induce fear when the meaning-making process is not supported. The findings of this study support the argument that teachers should be proactive in facilitating class talks in order to support children's meaning-making of media-intensive crises and catastrophes, both to ensure a basic feeling of safety and to promote a cognitive and reflexive mode of thinking.

\section{Strengths and limitations}

The open-ended qualitative interview provided rich empirical data that allowed us to explore the quality of these children's narrative structuring, both with teacher-supported and unsupported narratives. The findings contribute knowledge to the field of education on how to facilitate a safe learning environment for pupils dealing with crisis. The following limitations are relevant when interpreting the results of this study. Purposive sampling might have resulted in teachers volunteering who had a special interest and high activity in classroom communications. However, only two out of nine teachers had systematically engaged in such activity. Further, in the process of obtaining informed consent for participation in the study, pupils might have been primed about the topic by their parents. The interview material reveals that the majority of informants had remained interested in the attacks since they occurred and up until the time of interview. We are left with some uncertainty as to whether our selection procedures provided us with respondents who may have been more interested in the terror attacks than their peers. The findings should not be generalized but serve as an inspiration for further research and practical work of finding educational methods for supporting pupils in their meaning-making process of media-intensive crisis.

\section{Acknowledgments}

This study was funded by the Norwegian Ministry of Education and Research. We gratefully acknowledge the support of Sylvi Penne, Laila Aase, Åse Langballe, and Petra Filkukova for participating in discussions.

\section{Disclosure}

The authors report no conflict of interest in this work.

\section{References}

1. Gurwitch RH, Sitterle KA, Young BH, Pfefferbaum B. The aftermath of terrorism. In: La Greca AM, Silverman WK, Vernberg EM, Roberts MC, editors. Helping Children Cope with Disasters and Terrorism. Washington, DC: American Psychological Association; 2002:327-358.

2. Miguel-Tobal JJ, Cano-Vindel A, Gonzalez-Ordi H, et al. PTSD and depression after the Madrid March 11 train bombings. J Trauma Stress. 2006;19(1):69-80.

3. Norris FH, Friedman MJ, Watson PJ, Byrne CM, Diaz E, Kaniasty K. 60,000 disaster victims speak: Part I. An empirical review of the empirical literature, 1981-2001. Psychiatry. 2002;65(3):207-239.

4. Schuster MA, Stein BD, Jaycox L, et al. A national survey of stress reactions after the September 11, 2001, terrorist attacks. N Engl J Med. 2001;345:1507-1512.

5. Hoven CW, Duarte CS, Lucas CP, et al. Psychopathology among New York City public school children 6 months after September 11. Arch Gen Psychiatry. 2005;62:545-552.

6. Schultz JH, Langballe A, Raundalen M. Explaining the unexplainable: designing a national strategy on classroom communication concerning the 22 July terror attack in Norway. Eur J Psychotraumatol. 2014;5.

7. Janoff-Bullman R. The aftermath of victimization: Rebuilding shattered assumptions. In: Figley CR, editor. Trauma and its Wake: Vol 1. The Study and Treatment of Post Traumatic Stress Disorder. New York: Brunner/ Mazel cop.; 1985:15-35. 
8. Stern J. The Ultimate Terrorists. Cambridge, MA: Harvard University Press; 2000.

9. Philips D, Prince S, Shiebelhut L. Elementary school children's responses 3 months after the September 11 terrorist attacks: a study in Washington, DC. Am J Orthopsychiatry. 2004;74:509-528.

10. Saylor CF, Cowart BL, Lipovsky JA, Jackson C, Finch AJ Jr. Media exposure to September 11: Elementary school students' experiences and posttraumatic symptoms. Am Behav Sci. 2003;46:1622-1642.

11. Stuber J, Fairbrother G, Galea S, Pfefferbaum B, Wilson-Genderson M, Vlahov D. Determinants of counseling for children in Manhattan after the September 11 attacks. Psychiatr Serv. 2002;53:815-822.

12. Duarte CS, Wu P, Cheung A, et al. Media use by children and adolescents from New York City 6 months after the WTC attack. J Trauma Stress. 2011;24:553-556.

13. Thoresen S, Aakvaag HF, Wentzel-Larsen T, Dyb G, Hjemdal OK. The day Norway cried: Proximity and distress in Norwegian citizens following the 22nd July 2011 terrorist attacks in Oslo and Utøya Island. Eur J Psychotraumatol. 2012;3.

14. Penne S. Litteratur og Film i Klasserommet: Didaktikk for Ungdomstrinn og Videregående Skole [Fictional Texts and Films: Didatics for Lower and Upper Secondary School]. Oslo: Universitetsforl; 2010. Norwegian.

15. Polkinghorne DE. Narrative psychology and historical consciousness relationships and perspectives. In: Straub J, editor. Narration, Identity, and Historical Consciousness. New York: Berghahn; 2005;2-22.

16. Wertsch JV. Voices of Collective Remembering. Cambridge: Cambridge University Press; 2002.

17. Riessman CK. Narrative Analysis. Newbury Park, CA: Sage Publications Inc.; 1993.
18. Bruner JS. Acts of Meaning. Cambridge, MA: Harvard University Press; 1990.

19. Bruner JS. Frames for thinking: Ways of making meaning. In: Olson DR, Torrance N, editors. Modes of Thought: Explorations in Culture and Cognition. Cambridge: Cambridge University Press; 1996:93-105.

20. Penne S. Profesjonsfaget norsk i en endringstid [The L1-subject in a time of change] [PhD thesis]. Oslo: University of Oslo; 2006. Norwegian.

21. Gee JP. Social Linguistics and Literacies: Ideology in Discourses. Abingdon: Routledge; 2008.

22. Bruner JS. Actual Minds, Possible Worlds. Cambridge, MA: Harvard University Press; 1986.

23. Aase L. Litterære samtalar [Literary conversations]. In: Nicolaysen BK, Aase L, editors. Kulturmøte i Tekstar (Cultural Encounters in Texts). Oslo: Samlaget; 2005:106-124. Norwegian.

24. Appleyard JA. Becoming a Reader: The Experience of Fiction from Childhood to Adulthood. Cambridge: Cambridge University Press; 1991.

25. Vygotsky LS. Thought and Language. Cambridge, MA: MIT Press; 1986.

26. Bransford JD, Brown AL, Cocking RR, editors. How People Learn: Brain, Mind, Experience, and School. Washington, DC: National Academy Press; 1999.

27. Tishman S, Perkins DN, Jay ES. The Thinking Classroom: Learning and Teaching in a Culture of Thinking. Boston, MA: Allyn and Bacon; 1995.

28. Skarstein D. Meningsdannelse og diversitet: En didaktisk undersøkelse av elevers lesninger av norskfagets littercere tekster [Diversity and Meaning Making - A Didactic Study of Students' Reading of Fictional Texts] [PhD thesis]. Bergen: University of Bergen; 2013. Norwegian.

\section{Publish your work in this journal}

Psychology Research and Behavior Management is an international, peerreviewed, open access journal focusing on the science of psychology and its application in behavior management to develop improved outcomes in the clinical, educational, sports and business arenas. Specific topics covered include: Neuroscience, memory \& decision making; Behavior

\section{Dovepress}

modification \& management; Clinical applications; Business \& sports performance management; Social and developmental studies; Animal studies. The manuscript management system is completely online and includes a quick and fair peer-review system. Visit http://www.dovepress. com/testimonials.php to read real quotes from published authors. 